\title{
Forecast of Development of the Dual-Use Industrial Products Market
}

\author{
VERONIKA YU. CHERNOVA \\ Department of Marketing, \\ Peoples' Friendship University of Russia \\ 6 Miklukho-Maklaya Str., Moscow, 117198 \\ RUSSIAN FEDERATION \\ Institute of Marketing, \\ State University of Management. \\ 99, Ryazanskiy prospect st., Moscow, 109542 \\ RUSSIAN FEDERATION \\ EKATERINA A. DEGTEREVA \\ Department of Marketing, \\ Peoples' Friendship University of Russia \\ 6 Miklukho-Maklaya Str., Moscow, 117198 \\ RUSSIAN FEDERATION
}

\begin{abstract}
The purpose of the research is to analyse the market for dual-use industrial products in Russia and to make a forecast of its development through the example of the machinery and technical products export. The factors that affect the functioning of the dual-use product market are highlighted, including gross domestic product, the volatility index, oil price, and the dollar index. A multiplicative dynamic series decomposition model was used to forecast the export of dual-use machinery and technical products. It has been established that the export of dual-use machinery and technical products is characterised by a decrease in the medium-term forecast

period (2020-2024). To intensify market development, priority areas for cooperation and expansion of joint projects in the military-industrial complex have been formulated. The practical significance of the results

obtained is the ability to determine the points of innovative growth of the dual-use industrial products market in Russia.
\end{abstract}

Key-Words: - Dual-use products, Export, Multiplicative model, Industrial markets.

Received: September 15, 2020. Revised: December 16, 2020. Accepted: December 22, 2020.

Published: December 28, 2020.

\section{Introduction}

The military-industrial complex plays a special role in the development of any country's economy. However, in recent years, the trends of its functioning have changed greatly: the dependence of the armed forces and the defence industry on civil technologies is increasing. This raises the problem of searching for ways to engage the defence industry in collaboration with the civilian research sector, while the industry should seek to benefit from synergies in various sectors (European Commission, 2014). This requires a new approach to public administration and economic policy development.

These trends are also relevant for Russia, which today retains its place in the top five exporters of defence products (RBC, 2019). However, the development of the Russian market for dual-use products faces many problems, including a high level of dependence on imported components, a nondiversified list of consumer countries, and increased competition. One can agree that the Russian dual-use product market is focused on the implementation of military-technical and military-industrial policies, including two main areas - the modernisation of weapons, military equipment, and military production (Degtereva, \& Chernysheva, 2019). At the same time, it may be more expedient to reduce the segmentation between civilian and defence technologies, point-wise directing resources to the most promising areas. After all, enterprises that create high-tech products not only for military purposes but also for dual use, can play the role of a locomotive in the acquisition of advanced technologies (Mishin et al., 2019; Romanova et al., 2017). 
These circumstances actualise the need to determine the long-term development trajectories of the dual-use product market based on the forecast of its dynamics. The set goal implies solving the following tasks: to identify the characteristic features of the market to clarify the factors that affect its functioning; to determine the type of functional model for the dynamic series decomposition for making a forecast of exports of dual-use industrial products; to formulate priority areas for cooperation and expansion of joint projects in the militaryindustrial complex to intensify market development.

The article contains a review of the literature, an analysis of the features of the development of the dual-use product market, which made it possible to identify the factors affecting its functioning. We have built a forecast for the export of dual-use machine and technical products based on the multiplicative model of the dynamic series decomposition. Based on the results of the study, measures are proposed to ensure the efficient use of resources.

\section{Literature review}

The development of the dual-use product market is the subject of research by many scientists, such as Gunkin (2018), Domot (2019), Stasevich (2018); practically in all works, it is noted that this market belongs to the high-tech segment of the economy.

The term "dual-use products", by its general definition, means technologies that can be used for the development and the production of products for both military and civilian purposes (Frolova, 2017). These innovation areas have a wide range: energy for mobility; essential independent materials and components; health and sanitation protection, including against CBRN-E threats; communication, navigation, and surveillance systems; robotics; security/cybersecurity systems; manufacturing and supply chain solutions. Modern materials, nanoelectronics, information and communication technologies, unmanned systems, and automation are just a few examples of areas where military solutions can be used for civilian purposes (Matskulyak et al., 2019).

Terekhin (2004) speaks about the special legal status of dual-use products, which is determined by the danger of free circulation of this group of goods in the world market. The free sale of such products can lead to destabilisation of the international situation, and therefore it is necessary to strictly control the export of these products. Economic cooperation of the partner countries within the existing integration groupings is important for ensuring the effective functioning of the dual-use product market (Vinokurov, 2017). A review of the scientific literature on the opportunities and prospects of economic cooperation between various states has shown that this research area is relevant.

Researchers have accumulated significant experience in modelling and forecasting foreign trade. Taking into account the globalisation processes and increased competition, most often those factors and methods are used that best reflect the peculiarities of foreign trade of a particular country or a group of countries. At the same time, some scientists use existing macroeconomic models and try to improve them (Kaukin, \& Idrisov, 2013; Rastopchina, \& Sakharova, 2014; Troekurova, \& Pelevina, 2014), others develop their own models that best reflect the trend of foreign trade flows (Batkovasky et al., 2020; Bunin, 2010). Frolov (2004), Kapustina and Uzhitsky (2007), Bogomolov and Filko (2011) focus on the presence of specific factors, such as the policy of governments of countries that trade among themselves on environmental protection, which affect foreign trade. Matyas et al. (2000) and Schmidt and Koschel (1998), focusing on the theory of export/import forecasting, consider various methods depending on the forecast horizon, the degree of economic development, and the cultural and social values of the population. Stupakov (2018), considering integration, focuses on ensuring international and regional security; Javed and Munir (2016) and Hossain (2019) study the impact of exports on economic growth.

\section{Materials and Methods}

A multiplicative dynamic series decomposition model was used to forecast the export of machinery and technical products. When selecting factors for the export performance model, the authors were guided by the following considerations. First, the value of exports can be viewed in terms of both supply and demand. Second, export volumes are affected by the ratio of prices in the domestic and foreign markets. This ratio is considered favourable if the price in the domestic market is lower than the price in the external market. The corresponding volatility index VIX (Bloomberg, 2020a) was selected to characterise fluctuations in price conditions in the domestic and foreign markets. Third, a significant factor affecting export volumes is the exchange rate of the national currency against the US dollar. To characterise this factor, the U.S. Dollar Index (Intercontinental Exchange, 2020) was selected. The oil price is also important for commodity economies. The factors selected for modelling the export of dual-use products are as follows: world GDP (factor indicator); VIX Volatility Index (factor indicator); 
Brent oil price (factor indicator); USDX Dollar Index (factor indicator); EXP Export Volumes (performance indicator).

To assess the degree of adequacy of the constructed trend equation to the real process, let us calculate the average approximation error:

$$
\bar{\vartheta}=\frac{1}{n} \sum \frac{\left|y_{t}-\hat{y}_{t}\right|}{y_{t}} 100 \%
$$

The initial data for the corresponding calculations was statistics for the period 2010-2019 of the dualuse machinery and technical products export in Russia (Rosstat, 2020), as well as data on GDP, VIX volatility index, oil price, dollar index, Intercontinental Exchange (2020), and Bloomberg (2020b).

Many scientists were engaged in forecasting the dynamics of parameters of foreign economic activity. In most of the publications, various methods and models were used, which, with all their merits, can not accurately describe the development trends of the dual-use product market in modern conditions of integration processes. The use of the multiplicative model of the decomposition of the dynamic series made it possible to take into account the influence of important aspects both on the dependent variables and on the determinants. At the same time, it should be noted that there is a high likelihood of adjusting the proposed approach due to the ongoing coronavirus pandemic (COVID-19). First of all, this is due to intensive processes in the digital sphere, which is now growing rapidly, blurring the boundaries Lestari et al. (2020).

\section{Results}

The importance of the dual-use product market for the economy can be seen by analysing the structure of Russian exports (Fig. 1).

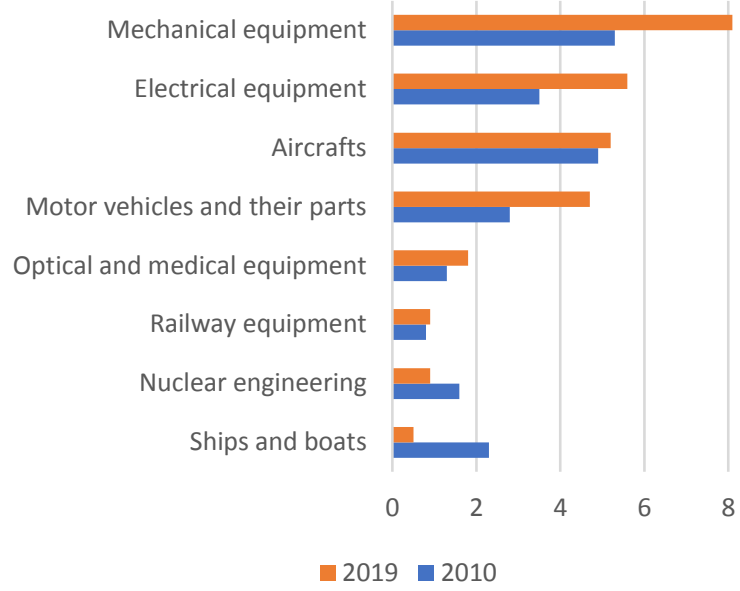

Fig. 1. Changes in the structure of Russian exports of dual-use machinery and technical products. Source: (Results of Foreign Economic Activity of Russia, 2020)

Based on the data, the parameters of the export model of dual-use machinery and technical products for the period 2010-2019 were compiled (Table 1).

Table 1. Indicators for modelling exports of dual-use machinery and technical products in Russia

\begin{tabular}{cccccc}
\hline Year & $\begin{array}{c}\text { Worl GDP, } \\
\text { trillion dollars }\end{array}$ & VIX & $\begin{array}{c}\text { BRENT, } \\
\text { dollars/barrel }\end{array}$ & USDX & $\begin{array}{c}\text { EXP, } \\
\text { billion dollars }\end{array}$ \\
\hline 2010 & 66.07 & 19.53 & 94.84 & 76.82 & 3.9 \\
2011 & 73.31 & 23.90 & 77.93 & 77.86 & 4.0 \\
2012 & 74.69 & 24.20 & 94.75 & 79.03 & 4.2 \\
2013 & 76.84 & 23.41 & 107.38 & 80.18 & 4.3 \\
2014 & 78.94 & 22.01 & 111.11 & 79.77 & 4.2 \\
2015 & 74.78 & 13.70 & 110.80 & 80.04 & 4.5 \\
2016 & 75.82 & 17.75 & 57.33 & 90.27 & 4.0 \\
2017 & 80.26 & 13.54 & 66.65 & 92.18 & 5.0 \\
2018 & 84.93 & 16.57 & 54.15 & 96.66 & 6.4 \\
2019 & 86.60 & 18.84 & 68.62 & 96.48 & 4.2 \\
\hline
\end{tabular}

Source: (Results of Foreign Economic Activity of Russia, 2020)

The regression model reflecting the influence of factors is as follows:

$\mathrm{EXP}=0.1288 * \mathrm{GDP}-0.1043 * \mathrm{VIX}-$ $-0.0227 *$ BRENT $-0.1077 *$ USDX +7.5253

Analysing the resulting regression, it can be argued that export growth is primarily due to GDP growth. Such variables as the volatility index, the oil price, and the dollar index had a negative impact on the dynamics of the performance indicator.

The value of the average approximation error of $8.876 \%$ indicates that the degree of adequacy of the regression equation to the real conditions of market development is average. 
The obtained model is reliable based on the Fcriterion (with a significance level of 5\%), and also individual parameters of the model are significant according to the t-Student criterion. The significance of the model coefficients was evaluated by comparing their values with their standard errors; the obtained actual values showed slight deviations from the calculated values, which suggests that the presented model correctly describes the dependence of exports on the selected factors.

At the same time, there are limitations, which are manifested, first of all, in the impossibility of forecasting using only the observed economic dependencies, most of which have a probabilistic and nonlinear nature. This statement leads to the fact that the authors can make a forecast for the medium term (2020-2024). The results are shown in Figure 2.

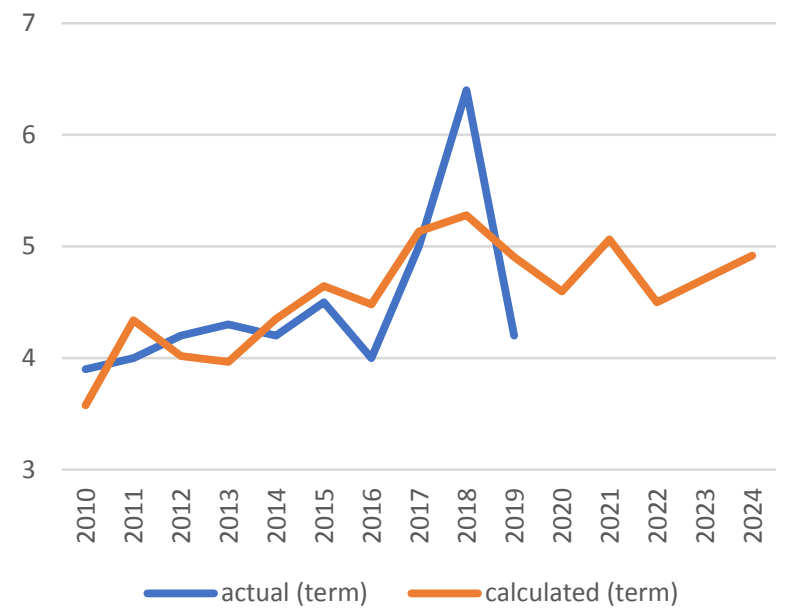

Fig. 2. Modelling of exports of dual-use machinery and technical products for the period 2010-2024

The obtained data points to an unstable state of Russian exports of dual-use machinery and technical products; there is an increase in the growth rate by an average of $0.36 \%$, which can be called insufficient taking into account the expected inflation. In other words, a small increase will be associated not with an increase in the supply of machinery and technical products, but with an increase in prices for them.

The forecast of exports of dual-use machinery and technical products in 2020-2024 indicates that the level of foreign trade will decrease in the future. New challenges facing the defence industry in Russia, as well as active participation in the EAEU and CSTO, outline the relevance of cooperation initiatives and the expansion of joint projects. The obtained forecast results can be used to identify areas of the dual-use product market that are characterised by export potential.

Thus, one of the priority areas is the development of defence industry clusters and expanding the participation of small and medium-sized enterprises in them. Today in Russia, small industrial companies are separately fragmented and have very small production capacities (Akberdina et al., 2018; Dellis et al., 2016; Dubrovsky, \& Ivanova, 2018; Litau, 2017), which is a serious obstacle to their active participation in cooperation projects. It is important to ensure the implementation of projects (even at a low level of technological readiness) to enhance data transfer between the military and non-military sectors, while expanding cooperation between military laboratories and civilian research to promote innovations. National and regional governments can support companies and research institutions in their diversification process by developing common technologies. Based on world practice, it can be argued that by increasing the number of companies with dual-use production capacities, the process of creating innovations is supported.

\section{Conclusion}

Summing up the conducted research, the authors can conclude that in modern conditions, the development of the dual-use product market is a priority export direction. The results of the market development forecast by the example of the machinery and technical products export showed the need to develop and implement comprehensive support measures. The forecast for the period of 2020-2024 indicates that the level of foreign trade will decrease in the future. The obtained forecast results can be used to identify areas of the dual-use product market that are characterised by export potential.

\section{References}

[1] Akberdina, V., Kalinina, A., \& Vlasov, A. (2018). Transformation stages of the Russian industrial complex in the context of economy digitization. Problems and Perspectives in Management, 16(4), 201-211. https://doi.org/10.21511/ppm.16(4).2018.17.

[2] Batkovsky, A.M., Batkovsky, M.A., \& Kravchuk, P.V. (2020). Choice of Options for Diversification of Production of Dual-Use Products. Actual Problems of Modern Economics, 3, 267-279.

[3] Bloomberg. (2020a). Chicago Board Options Exchange Volatility Index. Retrieved November 14, 2020, from https://www.bloomberg.com/quote/VIX:IND

[4] Bloomberg. (2020b). Retrieved November 14, 2020, from https://www.bloomberg.com/europe

[5] Bogomolov, V.A., \& Filko, I.V. (2011). Problems of Forecasting the Development of 
Enterprises in the Rocket and Space Industry. Actual Problems of Aviation and Astronautics, 2(7), 11-12.

[6] Bunin, A.S. (2010). Model for the Influence of External Investments on the Level of Income and the Size of Capital in One-Dimensional and Two-Dimensional Trade Structures. Modern Trends in Economics and Management: A New Look, 4-2, 123-126.

[7] Degtereva, E.A., \& Chernysheva, A.M. (2019). Military-Economic Cooperation of the CSTO and EAEU Member States with Third Countries: Challenges and Threats for Russia. Bulletin of the Peoples' Friendship University of Russia. Series: Economics, 27(4), 663-678.

[8] Dellis, K., Karkalakos, S., \& Kottaridi, C. (2016). Entrepreneurship Targeting Policies, Technological Growth, and Unemployment. Journal of Eurasian Economic Dialogue, 1(6), 19-39.

[9] Domot, O.N. (2019). The International Market for Military Products: Distinctive Features. Moscow Economic Journal, 1, 465-469. https://doi.org/10.24411/2413-046X-201911039.

[10] Dubrovsky, V.Zh., \& Ivanova, Ye.M. (2018). Changes in the Product Portfolio of Defence Contractors: Global Experience and Opportunities for Russia. Journal of New Economy, 19(2), 75-87.

[11] European Commission. (2014). EU Funding for Dual Use. Guide for Regions and SMEs. (p. 56).

[12] Frolov, I.E. (2004). Development Potential of the Knowledge-Intensive, High-Tech Sector of the Russian Industry. Forecasting Problems, 1, 79-100.

[13] Frolova, E.K. (2017). Dual-Use Products as an Object of Export Control: Problems of Legal Regulation in the Russian Federation and the USA. Problems of Economics and Legal Practice, 4, 75-80.

[14] Gunkin, E.M. (2018). The Current State of the Russian Military-Industrial Complex and Features of its Functioning. Bulletin of the Tula State University. Economic and Legal Sciences, 2-1, 94-102.

[15] Hossain, Md.M. (2019). Dynamic Growth Rate of U.S. Economy. Journal of Eurasian Economic Dialogue, 4(2), 1-17.

[16] Intercontinental Exchange. (2020). Retrieved November 14, 2020, from https://www.intercontinentalexchange.com/ind ex

[17] Javed, Z., \& Munir, K. (2016). Impact of Export Composition on Economic Growth in South
Asia. Journal of Eurasian Economic Dialogue, 1(3), 28-42.

[18] Kapustina, L.M., \& Uzhitsky, A.V. (2007). Forecast of the Development of the Russian Military-Industrial Complex Using Regression Analysis. Regional Economy, 1, 83-94.

[19] Kaukin, A., \& Idrisov, G. (2013). Gravitational Model of Russia's Foreign Trade: The Case of a Large in Area Country with a Long Border. Economic Policy, 4, 133-154.

[20] Litau, E. (2017). 'Evolution of Species' in Business: From Mice to Elephants. The Question of Small Enterprise Development. Journal of Advanced Research in Law and Economics, $\quad 8(6), \quad 1812-1824$. https://doi.org/10.14505/jarle.v8.6(28).16.

[21] Matskulyak, I.D., Sapozhnikova, N.T., \& Kharchilava, G.P. (2019). A Breakthrough Economy: On the Theory of Economic Systems Change Management. Upravlenets - The Manager, $\quad 10(4), \quad 75-84$. https://doi.org/10.29141/2218-5003-2019-10-47.

[22] Mátyás, L., Kónya, L., \& Harris, M.N. (2000). Modelling Export Activity of Eleven APEC Countries. Melbourne Institute Working Paper Series wp2000n05, Melbourne Institute of Applied Economic and Social Research, The University of Melbourne. Retrieved November 14, 2020, from https://ideas.repec.org/p/iae/iaewps/wp2000n05 .html

[23] Mishin, Yu.V., Kosterev, N.B., Sukharev, V.B., \& Mishin, A.Yu. (2019). Methods, Procedures and Tools for Diversifying Enterprises and Organizations of the Russian Defense Industry Complex. Modernization. Innovation. Development, 10(1), 38-53.

[24] Rastopchina, Yu.L., \& Sakharova, O.S. (2014). Foreign Trade Models: An Aspect of Macroeconomic Efficiency. Economics of Sustainable Development, 4(20), 185-191.

[25] RBC. (2019). SIPRI Named the World's Largest Arms Exporters. Retrieved November 14, 2020, from https://www.rbc.ru/politics/11/03/2019/5c85b2 a69a79471e4e0dd2e3

[26] Results of Foreign Economic Activity of Russia. (2020). Available at: https://economy.gov.ru/material/file/66eec 1250 c653fc9abd0419604f44bbd/VED.pdf

[27] Romanova, O.A., Korovin, G.B., \& Kuzmin, E.A. (2017). Analysis of the Development Prospects for the High-Tech Sector of the 
Economy in the Context of new Industrialization. Espacios, 38(59), 25.

[28] Rosstat. (n.d.) International Trade. Retrieved November $\quad 14, \quad 2020, \quad$ from https://rosstat.gov.ru/folder/11193

[29] Russian Export Centre. (n.d). Retrieved November 14, 2020, from https://www.exportcenter.ru

[30] Schmidt, T.F.N., \& Koschel, H. (1998). Modelling of Foreign Trade in Applied General Equilibrium Models: Theoretical Approaches and Sensitivity Analysis with the GEM-E3 Model. Retrieved November 14, 2020, from http://ideas.repec.org/p/zbw/zewdip/5181.html

[31] Stasevich, A.S. (2018). Review of the Global Arms and Military Equipment Market in 2016. Russian Foreign Economic Bulletin, 1, 106113. https://doi.org/10.24411/2072-8042-20180001.

[32] Stupakov, N.V. (2018). Formation of the Architecture of Greater Eurasia as a Transcontinental Space of a Multipolar World for the Development of Cooperation between Eurasian States and Ensuring International and Regional Security. Greater Eurasia: Development, Security, Cooperation, 1-2, 195198.

[33] Terekhin, N.V. (2004). International Legal Aspects of Export Control over the Transfer of Dual-Use and Military Products (on the Example of Russia and the USA) (Ph.D. Thesis). Moscow.

[34] Troekurova, I.S., \& Pelevina, K.A. (2014). Gravitational Models of Foreign Trade of the BRICS Countries. Izvestiya Saratov University. New series. Series: Economics. Management. Right, 14(1-2), 133-142.

[35] Vinokurov, E. (2017). Eurasian Economic Union: Current State and Preliminary Results. Russian Journal of Economics, 3, 54-70.

[36] Lestari, D., Caisar, D., \& Dio, D. (2020). International Trade in the COVID-19 Outbreak: Is the Digital Economy Working? Malaysian E Commerce Journal, 4(2) 60-62.

\section{Contribution of individual authors to the creation of a scientific article (ghostwriting policy)}

Veronika Yu. Chernova: formulation or evolution of overarching research goals and aims; Development or design of methodology; creation of models.

Ekaterina A. Degtereva: application of statistical, mathematical, computational, or other formal techniques to analyze or synthesize study data.

\section{Sources of funding for research presented in a scientific article or scientific article itself}

The article was prepared with the financial support of the Russian Foundation for Basic Research (RFBR), the project "Intensification of military-economic cooperation in the space of the Collective Security Treaty Organization and the Eurasian Economic Union in the context of the sanctions policy of developed countries and the development of import substitution in the Russian Federation", No. 18-01001132 .

\section{Creative Commons Attribution License 4.0 (Attribution 4.0 International, CC BY 4.0)}

This article is published under the terms of the Creative Commons Attribution License 4.0

https://creativecommons.org/licenses/by/4.0/deed.en_US 